\title{
Cultar (P333) a Boon for Mango Production - A Review
}

\author{
Satyendra Singh Narvariya* and C.P. Singh \\ Department of Horticulture, College of Agriculture, G. B. Pant University of Agriculture and \\ Technology, Pantnagar, U. S. Nagar (263 145) Uttarakhand, India \\ *Corresponding author
}

\begin{abstract}
A B S T R A C T
The ability to produce crops throughout the entire year is of great interest for mango production under sub-tropical and semi-arid conditions. The biennial bearing is very serious problem in north, east and central Indian commercial cultivars, while most of the

Keywords

Cultar, Mango,

Production

Article Info

Accepted:

15 January 2018

Available Online:

10 February 2018 south Indian varieties bear regularly. Therefore, application of cultar is most widely studied in view of its high potential for controlling plant growth and development of fruit crops in general and mango production in particular. It is applied either in the soil or as foliar spray in the September-November. The persistence of cultar in orchard soil for a long time and its half-life varies with soil type and climatic conditions, which may severely affect the development of subsequent crops and moved rapidly between the shoot tips and basal nodes both in the acropetal and basipetal directions and persisted for several months. It inhibits gibberellin biosynthesis at kaurene stage and has proved to be reduction of vegetative growth, promising for flower initiation in shoot bud, giving early and profuse flowering, increases fruit yield and improving quality regularly in alternate bearing cultivars. The main aim of this review is to focus upon contemporary information about cultar in mango production.
\end{abstract}

\section{Introduction}

Mango (Mangifera indica L.) belonging to the family Anacardiaceae, is the most important commercial fruit of India and considered as King of fruit, because of its rich, luscious, aromatic flavor and a delicious taste in which sweetness and acidity are delightfully blended. It is the most popular and the choicest fruit and occupies a prominent place among the fruits of the world. In India it is grown on an area of 2.516 million hectares with annual production of 18.431 million tonne having productivity of 7.3 metric tonne per hectare
Anonymous (2017). Although, alternate bearing is a major problems in mango production and its means "a condition at which high or optimum fruit production in on year or higher and certain year bear little or no fruit (off year), but growth regulators such as cultar reported to be effective on inducing flowering mango off year (Sinde et al., 2000). The alternate flowering in mango might be due to improper orchard management practices, environmental factors, varietal character, or imbalance of harmone, either alone or in combination. In addition to irregular bearing, canopy management and 
control tree vigour especially under semi-arid and tropical climate has become a challenge (Kurian et al., 2013). There are several strategies that control the problems of flowering periodicity and tree vigour in tropical and sub-tropical region such as the use of shoot pruning practices, dwarfing rootstock and growth regulators, the use of plant bioregulator is the most promising approach for managing canopy and ensuring regularity in flowering and enhancing fruit yield under commercial cultivation (Olivier et al., 1990).

It is a trizol derivative with the empirical formula [(2RS, 3Rs) -1 - (4-chlorophenyl) 4.4-dimethyl-2- (1H-1, 2, 4-triazole-1-yl) pentan-3-ol] being capable to inhibit the biosynthesis of gibberellins potentially (Sinde et al., 2000) and has been effectively used in reducing canopy volume and increasing flower intensity in mango (Nartvaranant et al., 2000). Cultar is effective not only in flower induction but also in early and off season flower induction in mango (Protacio et al., 2000, Blaikie et al., 2004, Yeshitela et al., 2004, Nafees et al., 2010, Burondkar et al., 2013). However, the Mode of action of plant growth regulators such as cultar, is highly specific to cultivar, rate of application, cultivar, developmental stages and climatic condition (Hoffmann1992). Thus, cultar holds considerable promise in manipulation of flowering, yield and vigour in fruit crops. However, its high potency for harmful to nature, slow mobility in the orchard soil, persistence in soil and fruit over its long term use (USEPA 2007). Hence, an effort was made to review the research work on the use of cultar in mango production.

\section{Physical and chemical properties of cultar}

Cultar is a plant growth inhibitor belonging to the triazole group. Chemical and physical properties are listed in Table 1.

\section{Application methods of cultar}

There are four application methods of cultar such as soil application, foliar application, trunk application, injection methods, out of which soil and foliar application mostly use in mango orchard. The application of cultar to soil as a drench around the tree trunk (TSLP) is the most effective method, as it ensures proper uptake by the tree. The required quantity is mixed in approximately one litre of water and poured onto the soil around the trunk in a circular band. In the Top End, the ideal time to apply cultar is from soon after harvest to early January. In dry conditions, a light irrigation is recommended after application. Foliar sprays have been ineffective. Fonseca (2004) reported that the effects of cultar $(0.5,1.0,1.5$ and $2.0 \mathrm{ml})$, applied either in the soil or as foliar spray, on the flowering and yield of mango cv. Tommy Atkins Therefore, soil application by trunk soil line pour (TSLP) (Tukey, 1983; Ferree and Schmid, 1988; Kim et al., 1990) and soil drench (Steffens et al., 1991) methods were attempted

\section{Mode of action and translocation}

Culrat is a compound of the triazole group, a very active group in plant growth control. Their capacity to reduce plant growth is due to their inhibiting of the kauren microsomal oxidation, which is catalyzed by the kaurene cytochrome oxidase P-450, the direct consequence of which is the inhibition of gibberellins synthesis. Cultar also acts on the inhibition of sterol biosynthesis; it reduces the amount of abscisic acid, ethylene, and indole3 -acetic acid, while augmenting the amount of cytokinins (Arteca, 1995). It may be absorbed by leaves, stems, and roots being translocated by the xylem up to the sub apical growth meristem where it will inhibit the synthesis of gibberellins and, consequently, cell elongation. Thus, Cultar absorbed in root was 
translocated rapidly to the shoot reaching the tip within 2 days of application but moved relatively slowly in the soil. cultar was absorbed much more slowly than that applied in spring and only a small amount was translocated upward (Fang and Huang, 1990). Browning et al., (1992) reported that cultar moved rapidly between the shoot tips and basal nodes both in the acropetal and basipetal directions and persisted for several months. Cultar has taken up by xylem and translocates acropetally to sub-apical meristem, where persistant effect can be provided (Sarkar et al., 1998).

\section{Influnecs the mechanism of nureint uptake}

The ability of roots to draw nutrients from the soil and to deliver these to the aerial plant tissues at a rate that matches the needs of growth is key to ensure physiological growth and development of plant, Whereas mismatch between the demand of the shoot and the supply from the roots can affect productivity (Tester and Leigh 2001). Kotur (2006) observed significant increase in the root activity towards the trunk and close to soil surface and sparser root activity in the subsoil zone and in drip line area in paclobutrazol treated mango plants. On the other hand, Werner (1993) observed an increase of N, Ca, $\mathrm{Mn}, \mathrm{Zn}$ and $\mathrm{B}$ contents and decrease of $\mathrm{P}, \mathrm{K}$ and $\mathrm{Cu}$ contents in cultar treated mango trees. Soil application of cultar $(2.0-8.0 \mathrm{~g} \mathrm{a}$ i) for two consecutive years in mango increased the levels of phosphorus, potassium and calcium at lower doses but decreased at higher dose. The findings indicate inhibitory effect of paclobutrazol at higher concentration on soil nutrient status and microbial population (Singh et al., 2005). PBZ also promotes the avoidance of salt stress in mango by increasing the levels of photosynthetic pigments, water content, $\mathrm{K}+$ uptake and uptake of harmful $\mathrm{Na}+$ and $\mathrm{Cl}-$ ions (Kishor et $a l ., 2009)$. The influence of paclobutrazol on leaf nutrient content lacks consistency as it showed variation with the crop species and soil conditions.

\section{Alter the phytoharmone/ endogenous harmone}

Phytoharmones play a crucial role in regulation of plant growth and development. There is an increasing evidence for a decisive function of certain hormones in the establishment of developmental programs of plants. Gibberellins are destined for vegetative growth, whereas cytokinin induces reproductive phase (Alabadí et al., 2009). The relative concentration of gibberellin and cytokinin decides the fate of the shoot. A significant decline in the GA3-like compounds was observed in the shoots of PBZ-treated plants after two months of application in mango and there was no difference in the level of GA3-like substance between control and treated plants one year after the treatment. This suggests the need for repeat application of cultar (Protacio et al., 2000). Upreti et al., (2013) reported that cultar besides affecting gibberellins also increases ABA and cytokinin, viz. zeatin $(\mathrm{Z})$, zeatin riboside (ZR) and dihydrozeatin riboside (DHZR), contents concomitant with $\mathrm{C}$ : $\mathrm{N}$ ratio and leaf water potential in mango buds to elicit flowering responses. In a similar findings, Singh and Sharma (2008) recorded increase in C:N ratio, leaf water potential, chlorophyll content, total sugar, total protein, nitrate reductase activity, ABA and cytokinins - zeatin (Z), zeatin riboside (ZR) and dihydrozeatin riboside (DHZR) in paclobutrazol treated mango. Adil et al., (2011) also recorded enhancement in the levels of zeatin (z), zeatin riboside (zr), isopentenyl Adenosine (i-Ado), isopentenyl Adenine (i- Ade), and abscisic acid (ABA), through at low level, along with the increase in startch and sugar contents in cultar treated trees of mango during the floral induction period. Whereas, gibberellins $(\mathrm{GA} 1+3+20)$ 
and auxin (IAA) were decreased during the same period. Cultar also induces morphological modifications such as enhanced leaf specific weight, stomatal density, leaf thickness, root-to-shoot ratio and root density that strengthen stress tolerance capacity in plants. Addionally, it has also fungicidal activity due to its inhibition of sterol biosynthesis (Chaney 2005, Fernandez et al., 2006).

\section{Efficacy of cultar on reduction of tree canopy}

It is a most integral part of modern fruit production technology which also restricts tree vigour hence trees should be allowed to develop a good canopy. Charnvichit et al., (1994) reported that cultar effectively regulated tree canopy and induced flowering in six year old pruned mango trees planted under high density system $(2.5 \mathrm{~m} \times 2.5 \mathrm{~m})$. The canopy regulation was due to the shortening of third and fourth flushes and intermodal lengths of the treated trees. The treated plants not only flowered more profusely but also were considerably earlier than the controls. However the treatment effect lasted for only one year. cultar was found effective in reducing tree vigour and in promoting flowering, fruit set and yield in Dashehari and Tommy Atkins (Singh 2000). Garcia et al., (2014) assessed the effect of pruning and cultar treatment on the vegetative growth and fruit yield of mango and reported that the efficacy of cultar in terms of shoot growth and production efficiency depends on the time of pruning. Ram et al., (2005) observed reduction in tree height, shoot length, shoot girth and internodal length when paclobutrazol (12 and $16 \mathrm{ml}$ ) applied with pruning (4 or $5 \mathrm{~m}$ height) of mango cv. Dashehari trees. Singh et al., (2000) reported that Soil drench applied paclobutrazol reduced tree height, shoot length, tree spread and panicle size in mango cv Dashehari. The reduction in xylem to phloem ratio caused dwarfing by the external application of $10 \mathrm{~g}$ cultar/tree in mango cv. Alphonso (Kurian and Iyer, 1992). Therefore, cultar in general has reduced the tree height and increased root-shoot ratio, besides increasing shoot number and tree spread in mango.

\section{Flower Bud Differentiation}

Flowering in mango is preceded by the differentiation of the flower bud in the shoots. Physiological maturity appears directly related with flower bud differentiation (Muhammad et al., 1999). In Indian sub-continent, the time of the flower bud differentiation has been reported by various workers to varying from October to December. In Baramasi mango bud differentiation, most often, takes place twice a year, i.e. during May- June and SeptemberOctober. Fluctuation in the time of flower bud differentiation is dependent on genetic, environmental and endogenous tree factors (Chaco, 1991; Schaffer et al., 1994). Thus, flower bud differentiation seems to be depending on the fluctuations in temperatures and the fruit load borne by the tree during previous year. Ravishankar et al., (1979) fond that flower bud differentiation in Alphonso mango, a irregular or erratic bearing cultivar grown under the mild tropical climate of Dharwar (India) was initiated in early October and reached a peak by November. Singh (1959) reported the last week of December to be the critical time for flower bud differentiation under north Indian climate.

\section{Regulation of flowering in off season}

The application of cultar before flower bud differentiation or three months earlier than anticipated flowering has been effective in inducing flowering in mango without accompanying reduction in shoot length. However higher concentration leads to canopy and panicle compaction (Shinde et al., 2000, 
Karki and Dakal 2003, Husen et al., 2012, Negi and Sharma 2009). Chusri et al., (2008) reported that in the PBZ treated trees bud break occurred 18-22 days earlier than in the control trees in 'Irwin' mango. Apical bud breaking exceeded $98 \%$ in the PBZ-treated trees compared with only $42 \%$ in the control trees. More than $96 \%$ of the PBZ-treated trees produced floral shoots, compared with only $35 \%$ of the control trees. The panicles of the PBZ-treated trees were shorter than those of the control trees. Apart from enhancing flowering intensity, cultar has also been effective in increasing sex ratio, cauliflory and axillary flowering in mango (Singh 2000). Cardoso (2007) observed that there was a higher percentage of flowering and fruit production as compared with the control. The PBZ treatment also anticipated flower initiation and fruit harvest, which means that out of season production, provides higher prices and more profitability.

Reddy and Kurian (2008) observed that under tropical climate, application of paclobutrazol for three consecutive years and then its discontinuation for the subsequent three years appears in twenty years old mango trees to be appropriate. However, the continous optimum use of cultar in high density planting is imperative to manage canopy and to induce precocious flowering as it was also observed that young plants respond better than old ones. Soil application around the tree trunk (collar drench) was more efficacious than foliar application as it ensures proper uptake in inducing flowering and fruiting (Kulkarni et al., 2006). On the other hand, Yeshitela (2004) reported that application of cultar both as a soil drench and foliar application were effective in suppressing vegetative growth and enhancing flowering, yield, fruit quality as well as number of hermaphrodite flowers in mango. The response to cultar varied with cultivar and crop load. The shoot retarding effect of cultar was generally limited in mango var. Sensation, but was pronounced in Tommy Atkin. Moreover the average fruit weight and yield were increased with the rate of paclobutrazol in Sensation, whereas fruit weight and yield were reduced in Tommy Atkin (Singh and Bhattacharjee 2005). Singh et al., (2005) reported soil application of PBZ at 5 and $10 \mathrm{~g} /$ tree considerably increased the percentage of panicles and hermaphrodite flowers on twenty five year old Dashehari mango trees. Soil application of paclobutrazol at $5 \mathrm{~g} /$ tree was most effective to induce more number of flowering shoots in mango cv. Gulab Khas (Singh and Singh, 2006). Mouco et al., (2005) observed that Paclobutrazol promoted flowering in mango trees in any season of the year, under tropical semi-arid conditions, but its efficiency was related to the maximum and minimum air temperatures at the time of bud break. Bagel et al., (2004) observed maximum number of flowering shoots/m2 $\quad(n=30.32)$ and percentage of flowering shoots (96.15\%) when Cultar applied alone $(2.50,3.75$ and $5.00 \mathrm{~g} / \mathrm{ha})$ and in combination with NAA (20 ppm), on the flowering and fruiting of 10-year-old mango $\mathrm{cv}$. Langra trees and they recorded flowering and fruiting was significantly increased by 7 $30 \%$. Soil application of Cultar promoted flowering, along with cauliflory and axillary flowering (Singh et al., 2000). Four months later and monthly thereafter, 10 shoots were dipped in $2 \%$ potassium nitrate to assess flowering response. Flowering started only by November or 6 months after paclobutrazol application. By December, all trees treated with 1 gram paclobutrazol per canopy diameter flowered in contrast to only $38 \%$ of the control trees. Starch content increased in stems of paclobutrazol-treated trees, suggesting that paclobutrazol promotes flowering by increasing starch accumulation (Protacio et al., 2000). The panicle size was reduced with the application of Cultar whereas the percentage of hermaphrodite flowers, fruit set and yield was increased. 
Table.1 Physical and chemical properties of cultar

\begin{tabular}{|c|c|c|}
\hline \multicolumn{2}{|r|}{ Cultar } & Source \\
\hline Structure & & U.S. EPA, 2007B \\
\hline Molecular Formula & C15H20CIN3O & U.S. EPA, 2007B \\
\hline IUPAC Name & $\begin{array}{c}(2 R S, 3 R S) \text {-1-(4-chlorophenyl)-4,4-dimethyl-2-(1H- } \\
\text { 1,2,4-triazol-1-yl)pentan-3-ol }\end{array}$ & U.S. EPA, 2007B \\
\hline Molecular Mass & 293.8 & EFSA, 2006 \\
\hline Melting/Boiling point & $164{ }^{\circ} \mathrm{C} / 384{ }^{\circ} \mathrm{C}$ & EFSA, 2006 \\
\hline Density & $1.23 \mathrm{~g} / \mathrm{cm} 3\left(20^{\circ} \mathrm{C}\right)$ & EFSA, 2006 \\
\hline Vapor Pressure & $1.9 \times 10-6 \mathrm{~Pa}$ (very slightly volatile & EFSA, 2006 \\
\hline Solubility in water & $26 \mathrm{mg} / \mathrm{L}\left(20^{\circ} \mathrm{C}\right)$ & BCPC, 2000 \\
\hline
\end{tabular}

Soil drench application of Cultar (20-40 $\mathrm{g} /$ tree) was the best treatment to reduce the tree vigour, promote flowering, fruit set and yield in Dusheri (Zora et al., 2000). The panicle size was reduced with the application of Cultar whereas the percentage of hermaphrodite flowers were increased (Singh et al., 2000). Paclobutrazol was applied in mango cvs. Chausa, Dashehari and Langra as soil drench @ 2, 4, 6 and $8 \mathrm{~g} /$ tree increased maximum flowering with more hermaphrodite flowers than control (Singh and Singh, 2003; Anbu et al., 2001).

\section{Duration and time of flowering}

Mango flowering is a key reproductive event for the production of fruit. Initiation is the first event that takes place for mangoes to flower (Davenport, 2000, 2003, 2009). The period between floral initiation and anthesis can be as little as 4 weeks under tropical conditions (Scholefield et al., 1986). The flowering of mango in India takes place as early as November - December in Rayalasema area of Andhra Pradesh (Gandhi, 1955), February - March in northern India (Singh, 1960) and slightly earlier (January February) in eastern part of the country. In
Fiji, flowering starts in July and extends through September /October (Iqbal, 19982), in Egypt during November to January (Nakhla, 1980). In northern India, mango flowers from February to March and the period of full bloom may sometimes be during the second fortnight of March. Thus, under the milder climatic conditions of southern and western India, flowering may starts from December, whereas under the climatic conditions of the north, it is late (February to March). In northern India the duration of flowering in mango is for about 20-25 days (Singh, 1960). It takes about a fortnight for the tiny bud to develop and open into a flower (Singh, 1990). The bloom period in eastern India is earlier than in north (Singh, 1978).

\section{Increase fruit set and yield}

Bagel et al., (2004) were recorded maximum yield per tree $(68.12 \mathrm{~kg})$, yield per hectare $(106.25 \mathrm{q} / \mathrm{ha})$, and yield increase over the control $(29.85 \%)$ of 10 year old mango cv. Langra trees applied with Cultar at $5.00 \mathrm{~g} / \mathrm{ha}$ in combination with $20 \mathrm{ppm}$ NAA. Soil application of paclobutrazol at $5 \mathrm{~g} /$ tree was most effective to improve the fruit set and 
fruit retention during the off year. The highest yields of 70.50 and $68.70 \mathrm{~kg}$ per tree during the off year were recorded under soil application of paclobutrazol at 5 and 10 g/tree, respectively (Singh and Singh, 2006). Increase in fruit set per panicle is due to retardation of plant vigour by growth retardant. Benjawan (2005) reported that PBZ had no significant effect in extending number of days from flower initiation up to full bloom. PBZ also had no significant effect in delaying fruit maturity age but fruit sets were significantly increased with PBZ rates applied. PBZ had a highly significant effect on fruit length but significantly decreased fruit thickness. Fruit yields were significantly increased with PBZ application. The best application rate of PBZ was found with $\mathrm{T}<$ sub $>7</$ sub> (1000 ppm/plant) with an extended flower raceme length of $5 \mathrm{~cm}$. This treatment gave the highest mango edible fruit yield of $48281.25 \mathrm{~kg}$ ha-1. Paclobutrazol was applied in mango cvs. Chausa, Dashehari and Langra as soil drench @ 2, 4, 6 and 8 g/tree and recorded maximum fruits set per panicle, fruit number and fruit yield per tree in $4 \mathrm{~g} /$ tree treated Dashehari tree whereas $6 \mathrm{~g} /$ tree of PP333 was found more effective in cvs. Chausa and Langra (Singh and Singh, 2003). Soil drenching of PP333, 5 or $10 \mathrm{ml}$ at 120 , 90 and 60 days before bud break on mango cv. Neelum and recorded the maximum number of fruits (380) and fruit yield per tree $(91.65 \mathrm{~kg})$ both in off season and main season (302 fruits and $72.85 \mathrm{~kg}$ per tree) with $5 \mathrm{ml}$ of PP333, 90 days before bud break (Anbu et al., 2001).

\section{Improve Fruit Quality}

Due to cultar application chemical composition of fruits was considerably enhanced in terms of TSS, total sugars, ascorbic acid, TSS/acid ratio, however, there was depletion in titratable acidity in freshly harvested fruits. These results are in conformity with the reports of Vijaylakshmi and Srinivasan (2000) in mango. Fruit quality of mango (TSS and acid content) increases with paclobutrazol application (Burondkar et al., 2013). The effect was more pronounced in fruits that received 2000 or $3000 \mathrm{mg} \mathrm{l}^{-1}$ than lower doses. These treatments attained better quality as judged from the total soluble solids, total acidity, ascorbic acid content, total chlorophyll, total carotenoids, and amylase and peroxidase activity from harvest to 12 days of storage at ambient conditions. Chemical parameters of fruits (Reddy and Kurian, 2008) such as TSS and acidity were not affected by cultar but average weight of a fruit was less in the case of cultar treatments. The effects of cultar applications on fruit size in mango cv. Sensation, and on fruit retention in Tommy Atkins, were investigated in the Northern Province of South Africa. One or 10 $\mathrm{ml}$ of paclobutrazol (as Cultar) was diluted with water to $100 \mathrm{ml}(0.25$ or $2.50 \mathrm{~g}$ a.i. $)$, and was applied to a 60 -cm-diameter ring of soil around the trunk of 2-year-old trees prior to the initiation of postharvest flushing.

In Sensation, the average fruit weight (final fruit size) and tree revenue increased with increasing rates of paclobutrazol applied. The number of fruits retained and yields were not affected. In Tommy Atkins, the number of fruits retained, average fruit weight, yield and tree revenue decreased with increasing rates of cultar applied (Oosthuyse et al., 1997). The treatment also improved the fruit quality in terms of total soluble solids (TSS), total acidity, total chlorophyll, total carotenoids, alpha-amylase and peroxidase activity. The relation of cultar on the water use in terms of soil moisture content, gas exchange attributes of Dashehari mango was also studied indicated that the cultar has capacity to retain the moisture to some extent and the trees are less sensitive to fluctuation in water supply and may be better able to withstand drought conditions (Singh and Singh, 2003). 


\section{Persistence in mango fruits}

Paclobutrazol has prolonged persistence in plant system due to its slow rate of metabolism (Sterrett 1985). However it has differential translocation rate among different plant parts. Neidhart et al., (2006) and Costa et al., (2012) observed that PBZ did not translocate into the mango fruits, as assumed from its mode of translocation. On the other hand, Srivastav and Ram (1999) confirmed the translocation of PBZ into fruits and seeds of Dashehari, Langra, Chausa and Fazli though the concentration was below permissible limits. Similar findings were also obtained by Sharma and Awasthi (2005) who reported $0.05 \mathrm{ppm}$ residue of $\mathrm{PBZ}$ (the maximum residual level for stone fruits) in unripe mango with the application of PBZ @ 5 to $10 \mathrm{~g}$ a.i. per tree for three consecutive years. Moreover the level further decreased to $0.001 \mathrm{mg} / \mathrm{kg}$ at fruit maturity.

\section{Degradation and persistences in orchard soil}

Paclobutrazol is characterized by moderate potential of mobility in soil which enables it is applied in soil unlike other growth regulators (Costa et al., 2012), however its mobility varied with the soil type. Studies conducted in USA indicate that half-lives of paclobutrazol residues ranged from 450-950 days for orchard soils which indicates poor degradation rate of PBZ. Paclobutrazol showed low soil adsorption coefficient $(\mathrm{KD}=$ 1.3 to $23.0 \mathrm{ml} / \mathrm{g}$ ), however adsorption appeared to increase with soil organic matter and a decrease in soil $\mathrm{pH}$. Studies conducted in USA revealed that less than $10 \%$ of total PBZ applied were detected in soils between the depths of $60-120 \mathrm{~cm}$, whereas the PBZ ketone metabolite was predominately detected in the subsurface soil layers though at insignificant levels. Sharma and Awasthi (2005) detected residues of paclobutrazol in the tree basin soil $(0-15 \mathrm{~cm})$ at the end of each season followed by a slight increase in the amount of residues with the year of applications. Reddy and Kurian (2008) also observed residual influence of PBZ in soil if applied continuously for three consecutive years and suggested discontinuation of application or to taper down its dose. Sharma et al., (2008) could not detect paclobutrazol residues above quantifiable levels $(0.01 \mathrm{ppm})$ either in tree basin surface soils or in the fruits even after more than five years continuous application. However, they further reported that the residues increased to $0.34 \mathrm{ppm}$ with the increase of the application rate $(20 \mathrm{~g}$ a. i./tree). Singh and Bhattacharjee (2005) also detected paclobutrazol residue below permissible limit $(0.4898-1.0005 \mu \mathrm{g} / \mathrm{g})$ in the rhizosphere after two years of application. Jaradrattanapaiboon et al., (2008) reported spatial difference of paclobutrazol residue in soils as they observed high concentration of PBZ residue in upper soil layer $(0-5 \mathrm{~cm})$ and low residue level in lower soil layer (10- 20 $\mathrm{cm})$. They further reported that PBZ persisted for about 3-5 months. On the other hand, Narvaranant et al., (2000) reported the persistence of PBZ residue up to 12 months Ochoa et al., (2009) expressed the possibility of environmental contamination with the regular application of paclobutrazol in containerized oleander production due the leaching of PBZ into the nursery soil with the irrigation water. The adsorption and leaching of the residues is dependent upon the soil physical and chemical characteristics as well as environmental factors such as rainfall. Wu et al., (2013) have reported that paclobutrazol was more persistent in greenhouse than in open field soil; leaching by rainfall being responsible for the difference in dissipation. Paclobutrazol is also known to leach in soil with high sand content.

Conclusions of this review indicate that the cultar is a growth inhibitor and also belong to 
triazol group. It is inhibit the biosynthesis of GA3 at kaurene stage. The cultar is most commonly used for the induction of flowering in off season, control tree vigour for HDP (canopy managment), increase fruit set and yield, improve fruit quality when applied to the soil but has the drawback of relatively high persistence in both soil and fruit in mango. Studies aiming to adjust the amount of application dose of cultar to each cultivar will allow the formulation of recommendations for more efficient applications, which can not only provide quality fruit production throughout the year but also reduce the risk of residues in the mango orchard soil, tree, fruit and environment.

\section{References}

Anbu, S., Parthiban, S., Rajangam, J. and Thangaraj, T. 2001. Induction of off season flowering in mango (Mangifera indica L.) using paclobutrazol. South Ind. Hort., 49: 384-385.

Anonymous, 2010. Agricultural Processed Food and Export Development Authority (APEDA), New Delhi.

Anonymous, 2017. NHB, Gurgaon, Haryana.

Arteca, R. N. 1995. Plant growth substances: principles and applications. New York: Champman \& Hall,pp. 332

Bagel, B.S., Tiwari, R. and Gupta, N. 2004. Effect of cultar and NAA on flowering and fruiting of mango (Mangifera indica L.) cv. Langra. South Ind. Hort., 52(1/6): 302-304.

Benjawan, C., Chutichudat, P., Boontiang, K. and Chanaboon, T. 2006. Effect of chemical paclobutrazol on fruit development, quality and fruit yield of Kaew mango (Mangifera indica L.) in Northeast Thailand. Pakistan Journal of Biological Sciences, 9(4): 717-722

Burondkar M M, Rajan S, Upreti K K, Reddy Y T N, Singh V K, Sabale S N, Naik M
M, Ngade P M and Saxena P. 2013. Advancing Alphonso mango harvest season in lateritic rockysoils of Konkan region through manipulation in time of paclobutrazol application. Journal of Applied Horticulture 15: 178-82

Cardoso, M.G.S., Jose, A.R.S., Viana, A.E.S., Matsumoto, S.N. and Reboucas, T. N.H. 2007. Flowering and production of mango fruits (Mangifera indica L.) cv. Rosa promoted by different paclobutrazol doses. Revista Brasileira de Fruticultura, 29(2): 209-212.

Chusri, O., Kozai, N., Ogata, T., Higuchi, H. and Yonemoto, Y. 2008. Application of paclobutrazol for flowering and fruit production of 'Irwin' mango (Mangifera indica L.) in Okinawa. Tropical Agriculture and Development, 52(3): 69-73.

Davenport, T.L. 2008. Reproductive physiology. In: Litz RE (ed), The Mango, Botany, Production and Uses. $2^{\text {nd }}$ Edition. $C A B$ International, Wallingford Oxon. In press.

Davenport, T.L., 2000. Processes influencing floral initiation and bloom: the role of phytohormones in a conceptual flowering model. Hort. Tech., 10: 733739.

Davenport, T.L., 2003. Management of flowering in three tropical and subtropical fruit tree species. Hort. Sci., 38: $1331-1335$

Davenport, T.L., 2007. Reproductive physiology of mango. Braz. J. Plant Physio., 19: 363-376.

Davenport, T.L., 2009. Reproductive physiology. In: Litz, R.E. (Ed.), The Mango: Botany Production and Uses, 2nd edition. CAB International, Wallingford, UK, pp. 97-169.

EFSA, 2006. Paclobutrazol Draft Assessment Report (DAR). Report and proposed decision of the United Kingdom made to the European Commission. Available 
at: $\quad$ http://dar.efsa.europa.eu/darweb/provision

EPA, U.S., 2007B. Paclobutrazol summary document for registration review: Initial Docket. Case Number 7002. Available in docket number EPA-HQ-EPA-20060109 at regulations.gov.

Fonseca, N., Castro, N.M.T. and Ledo, C.A. 2004. Paclobutrazol on flowering and production of 'Tommy Atkins' mango. Ciencia e Agrotecnologia, 28(4): 807814.

Kulkarni, V. J. 1988: Chemical control of tree vigour and the promotion of flowering and fruiting in mango (Mangifera indica L.) using paclobutrazol. Journal of Horticultural Sciences 63: 557-566.

Mouco, M.A.d.C., Albuquerque, J.A.S. 2005. Paclobutrazol effect at two mango production cycles. Bragantia, 64: 2, 219-225.

Pandey, S.N. and Dinesh, M.R. 2010. Mango, Indian Council of Agricultural Research, New Delhi. pp. 30- 97.

Protacio, C.M., Bugante, R.D., Quinto, J., Molinyawe, G. and Paelmo G. 2000. Regulation of flowering in 'carabao' mango trees by paclobutrazol. Philippine Journal of Crop Science, 25(1): 27-33.

Rajkumar, M., Reddy, Y.N., Chandrasekhar, R. and Srihari, D. 2007. Studies on the effect of foliar application of chemicals and groth regulators on the fruit yield of unpruned mango (Mangifera indica L.) trees cv. Baneshan. The Orissa J. Hort., 3(2): 44-47.

Ram, R.B., Vismil, R.S. and Lal, B. 2005. Effect of pruning severities and paclobutrazol on bearing behaviour of rejuvenated mango trees cv. Dashehari. New Agriculturist, 16: 1-9.

Rath, S. and Rajput, C.B.S. 2000. Effect of B napthoxy acetic acid and gibberellic acid on chemical composition of mango fruits. Orissa J. Agric. Res., 3(2): 155-
156.

Reddy, Y.T.N., Kurian, R.M. 2008. Cumulative and residual effects of paclobutrazol on growth, yield and fruit quality of 'Alphonso' mango. Journal of Horticultural Sciences, 3(2): 119-122.

Sharma, R.R. and Singh, R. 2006. Pruning intensity modifies canopy microclimate, and influences sex ratio, malformation incidence and development of fruited panicles in 'Amrapali' mango (Mangifera indica L.). Scientia Horticulturae, 109: 118-122.

Shinde, A.K., Waghmare, G.M., Wagh, R.G., Burondkar, M.M. 2000. Effect of dose and time of paclobutrazol application on flowering and yield of mango. Indian Journal of Plant Physiology, 5(1): 8284.

Shinde, A.K., G.M Waghmare., R.G, Wagh, R.G and M.M Burondkar, 2000. Effect of dose and time of paclobutrazol application on flowering and yield of mango. Indian J. Plant Physiol. 5. (5): 82-84.

Singh, D.B. and Ranganath, H.R. 2006. Induction of regular and early fruiting in mango by paclobutrazol under tropical humid climate. Ind. J. Hort., 63(3): 248249.

Singh, N.P., Malhi, C.S. and Sharma, R.C. 2005. Effect of plant bio regulators (PBRs) on flowering, fruit yield and quality in mango cv. Dashehari. Horticultural Journal, 18(1): 10-12.

Singh, R.N. 1958. Studies in the differentiation and development of fruit bud in mango. II Morphological and histological changes. Hort. Adv., 2: 37.

Singh, S.and Singh, A.K. 2006. Regulation of shoot growth and flowering in mango cv. Gulab Khas by paclobutrazol. Annals of Agricultural Research, 27(1): 4-8.

Singh, V.K. and Singh, A. 2003. Effect of paclobutrazol on regularity of bearing in 
mango (Mangifera indica L.). Physiology and Molecular Biology of Plants, 9(2): 239-248.

Singh, Z., Muller, W., Polesny F. (ed.); Verheyden. C (ed.) and Webster, A.D. 2000. Effect of (2RS, 3RS) paclobutrazol on tree vigour, flowering, fruit set and yield in mango. Proceedings of the international conference on integrated fruit production, Leuven, Belgium, 27 July-1 August 1998. Acta-Horticulturae, 525: 459-462.

Srivastava, R.P. and Kumar, S. 2009. Fruit and vegetable preservation: Principles and Practices, $360 \mathrm{p}$.

Susila, T., Reddy, S.A., Rajkumar, M., Padmaja, A. and Rao, P.V. 2010. Effect of plant growth regulators on flowering and yield of watermelon (Citrullus lanatus T.). J. Hort. Sci. and Ornamental plants, 2:1 19-23.

Vijaylakshmi, D. and Srinivasan, P.L. 2000. Improving the quality attributes of 'off' year Alphonso mango through chemicals and growth regulators. The Orissa J. Hort., 28 (1):31-33.

Whiley, A.W., Wolstenholme, B.N. and Saranah, J.B. 1988. Canopy management toward 2000. "Avocados Toward 2000" Australian Avocado Bicentennial conference, At Caloundra, Australia. pp. 44-50.

Zora, S., Singh, Z., Muller, W., Polesny, F., Verheyden, C. and Webster, A.D. 2000. Effect of (2RS, 3RS) paclobutrazol on tree vigour, flowering, fruit set and yield in mango. Acta Hort., 525: 459462.

\section{How to cite this article:}

Satyendra Singh Narvariya and Singh, C.P. 2018. Cultar (P333) a Boon for Mango Production - A Review. Int.J.Curr.Microbiol.App.Sci. 7(02): 1552-1562.

doi: https://doi.org/10.20546/ijcmas.2018.702.187 